\title{
Avian Communities of the Northern Mackenzie Mountains, Northwest Territories, Canada
}

\author{
Kevin J. Kardynal, ${ }^{1,2}$ Blake A. Bartzen ${ }^{1,3}$ and Paul B. Latour ${ }^{1}$
}

(Received 14 July 2014; accepted in revised form 7 January 2015)

\begin{abstract}
Basic knowledge of the abundance and distribution of birds and their habitats and the relationships between them is limited for many parts of Arctic Canada, including montane regions. This information is important for conservation purposes as bird populations and habitats shift and as interest in development of northern areas increases. We characterized bird communities in the Mackenzie Mountains of the Northwest Territories by conducting point counts $(\mathrm{n}=376)$ in June 2009 and 2010 and using community analysis metrics (multiple response permutation procedures, indicator species analysis, non-metric multidimensional scaling) to statistically and graphically describe bird data in six habitat types: coniferous forest, deciduous forest, shrub (short and tall), alpine tundra, and open water wetlands. Distinct habitats had significantly different bird communities, as shown by using multiple response permutation procedures $(p<0.005)$. Of 51 species, 32 had significant $(p<0.05)$ indicator values for one habitat type $(\mathrm{n}=15)$ or groups of habitats $(\mathrm{n}=17)$ in an indicator species analysis. The tall shrub habitat type had the most indicator species (six species) followed by alpine tundra (five species), then the combined conifer, deciduous, and wetland habitat group (four species) and the deciduous forest habitat types (three species). Species richness was highest in the tall shrub $(n=37)$, alpine $(n=30)$, and conifer and short shrub $(n=29)$ habitats. We also observed eight bird species not previously known to occur in the area, or which were outside published ranges. Our results highlight the variability in bird community composition between the major habitat types in the Mackenzie Mountains, serve as a baseline for future bird studies in the region, and underscore the need for more research in the area with impending anthropogenic changes.
\end{abstract}

Key words: alpine; bird community; climate change; Mackenzie Mountains; Northwest Territories; passerine; tundra

RÉSUMÉ. Pour de nombreuses parties de l'Arctique canadien, y compris les régions montagnardes, les connaissances de base portant sur l'abondance et la répartition des oiseaux et de leurs habitats, de même que sur leurs relations entre eux, sont restreintes. Ces renseignements revêtent de l'importance en matière de conservation, au moment où les habitats et les populations d'oiseaux changent et où l'on s'intéresse de plus en plus au développement des régions du nord. Nous avons caractérisé les communautés d'oiseaux des monts Mackenzie, dans les Territoires du Nord-Ouest, en effectuant des dénombrements ponctuels $(\mathrm{n}=376)$ en juin 2009 et 2010 et en recourant à diverses mesures d'analyse des communautés (test de permutations multiples, analyse des espèces indicatrices, analyse multidimensionnelle non métrique) afin de décrire à l'aide de statistiques et de graphiques les données relatives aux oiseaux de six types d'habitats : forêts de conifères, forêts de feuillus, arbustaies (petits arbustes et grands arbustes), toundra alpine et terres humides avec étendues d'eaux libres. D'après les tests de permutations multiples $(p<0,005)$, les communautés d'oiseaux diffèrent considérablement en présence d'habitats distincts. L'analyse des espèces indicatrices a également permis de démontrer que parmi les 51 espèces, 32 avaient des valeurs indicatrices importantes $(<0,05)$ pour un type d'habitat $(n=15)$ ou des groupes d'habitats $(n=17)$. L'habitat des grands arbustes comptait le plus grand nombre d'espèces indicatrices (six espèces), suivi de la toundra alpine (cinq espèces), puis du groupe composé de la forêt de conifères, de la forêt de feuillus et des terres humides (quatre espèces), et de la forêt de feuillus (trois espèces). La richesse des espèces était plus grande dans les habitats des grands arbustes $(n=37)$, de la toundra alpine $(\mathrm{n}=30)$ et des conifères et petits arbustes $(\mathrm{n}=29)$. Nous avons également observé huit espèces d'oiseaux qui n'avaient jamais été répertoriées dans la région ou qui se trouvaient en dehors de leur parcours naturel. Nos résultats mettent en évidence la variabilité de la composition des communautés d'oiseaux dans les principaux types d'habitats des monts Mackenzie. Ils serviront également de référence aux autres études d'oiseaux qui seront effectuées dans la région, et font ressortir la nécessité de faire d'autres recherches dans la région à la lumière des changements anthropiques imminents.

Mots clés : alpin; communauté d'oiseaux; changement climatique; monts Mackenzie; Territoires du Nord-Ouest; passereau; toundra

Traduit pour la revue Arctic par Nicole Giguère.

\footnotetext{
${ }^{1}$ Canadian Wildlife Service, Environment Canada, PO Box 2310, Yellowknife, Northwest Territories X1A 2P7, Canada

${ }^{2}$ Corresponding author, present address: Science and Technology, Environment Canada, 11 Innovation Boulevard, Saskatoon, Saskatchewan S7N 3H5, Canada; Kevin.Kardynal@ec.gc.ca

${ }^{3}$ Present address: Canadian Wildlife Service, Environment Canada, Saskatoon, Saskatchewan S7H 0X4, Canada

(C) Her Majesty the Queen in Right of Canada. Administered by the Arctic Institute of North America
} 


\section{INTRODUCTION}

Compared to other parts of the world, northern Canada is sparsely populated, has limited human activity, and features large tracts of undisturbed wildlife habitat. However, high resource potential (Gal and Pyle, 2012; Ozyer, 2012) has led to increased interest in exploration and development in the region, causing greater environmental pressures. Alpine and Arctic areas are also expected to undergo significant changes in coming decades as a result of climate change (Liang and Kershaw, 1995; ESTR Secretariat, 2011). These changes are likely to include altered vegetation composition (Lantz et al., 2013) and plant phenology (Ernakovich et al., 2014), which could cause mismatches in the timing between prey emergence and critical periods in the breeding season (McKinnon et al., 2012). These impacts may lead to cascading effects on wildlife and their habitats (Hinzman et al., 2005; Grabowski et al., 2013; Virkkala and Lehikoinen, 2014).

The impacts of anthropogenically induced changes to natural ecosystems and the intensification of human activities (e.g., forestry) have led to declines of many species across North America (NABCI Canada, 2012). Northern ecosystems, including the Mackenzie Mountains, with only minor anthropogenic disturbance, represent a unique and valuable opportunity to assess baseline wildlife relationships, which is crucial to implementing sustainable, ecosystem-based planning (Niemi et al., 1998). Knowledge of bird-habitat associations can also be used to inform bird monitoring programs and to model species distributions. This knowledge is important for predicting how future environmental changes may affect wildlife, and it can provide important information for mitigating impacts from proposed developments.

Birds are important components of northern ecozones and are considered good indicators of environmental change because the responses of many species to disturbance, changes in habitat and prey, and fluctuations in climate are well known (Canterbury et al., 2000). Bird research and monitoring have been limited in the Mackenzie Mountains, a region along the Northwest Territories and Yukon border. Prior to this study, the only major published ornithological work for the region was based on research conducted in the Yukon in 1944 (Rand, 1946). However, some bird surveys and research associated with environmental assessments for proposed developments have focused on game birds (e.g., AMAX Inc., 1983) or raptors (Barichello, 1983) or on Nahanni National Park Reserve to the south (Scotter et al., 1985). Additionally, many of the bird species that occur in northern Canada are poorly covered by the continental Breeding Bird Survey (BBS; Dunn et al., 2005), the primary dataset used to estimate population trends and sizes (NABCI Canada, 2012).

The objectives of this study were to determine abundance (at the point-count scale), species richness, composition, and variation of bird communities in available habitats in the remote Mackenzie Mountains of the
Northwest Territories. This information allows for comparison with available information from boreal forest and cordilleran areas south of the Mackenzie Mountains (e.g., northern Rocky Mountains). With a high diversity in vegetation composition and structure and other biotic and abiotic characteristics in the northern Mackenzie Mountains, we predicted that bird communities would exhibit considerable variation between habitat types. We also expected that habitat types with greater structural heterogeneity, such as treed and wetland habitats, would have more indicator species and higher richness than more uniform habitats, such as alpine and short shrub.

\section{METHODS}

\section{Study Area}

The study area, approximately $58000 \mathrm{~km}^{2}$, lies in the Mackenzie Mountains within the Taiga Cordillera ecozone (Fig. 1). The Mackenzie Mountains are a northern extension of the eastern Rocky Mountains and are considered part of the boreal forest biome (Brandt, 2009). The ecozone is characterized by broad river valleys, low-relief plains, plateaus and foothills from $300 \mathrm{~m}$ to $1000 \mathrm{~m}$ above sea level (asl), and high-elevation plateaus, peaks, and long ridges over $1500 \mathrm{~m}$ asl (Ecosystem Classification Group, 2010). Mean annual temperatures are $-7^{\circ} \mathrm{C}$ with mean winter temperatures in January and February of $-30^{\circ} \mathrm{C}$ and mean summer temperatures of $16^{\circ} \mathrm{C}$ (Ecosystem Classification Group, 2010). The Mackenzie Mountains are located in the precipitation shadow of the Selwyn Mountain range to the west, and precipitation decreases with increasing latitude and altitude. More precipitation occurs near the Yukon-Northwest Territories border than farther east, ranging from 280 to $350 \mathrm{~mm}$ annually, mostly in the summer months (May-September). Part of the region was covered by ice sheets during the most recent glaciation (19000 to 24000 years ago); however, some areas have remained ice-free for the last 250000 years (Ecosystem Classification Group, 2010).

High variability in elevation, slope, aspect, climate, and other abiotic factors results in diverse vegetation communities and habitat structure (Canadian Wildlife Service, 2009). River valleys at lower elevations typically contain closed-canopy conifer, mixedwood, or deciduous forests typical of boreal regions and are dominated by black spruce (Picea mariana), paper birch (Betula papyrifera), or trembling aspen (Populous tremuloides). Black spruce forests also occur on poorly drained organic and mineral soils that are usually underlain by permafrost (Ecosystem Classification Group, 2010). Low elevation, south-facing slopes away from river valleys are characterized by mostly opencanopy black spruce. The timberline is low, leaving many upper slopes bare or with little vegetation. The plant communities found on low-relief, high-elevation plateaus are typically dominated by graminoid vegetation, resembling 


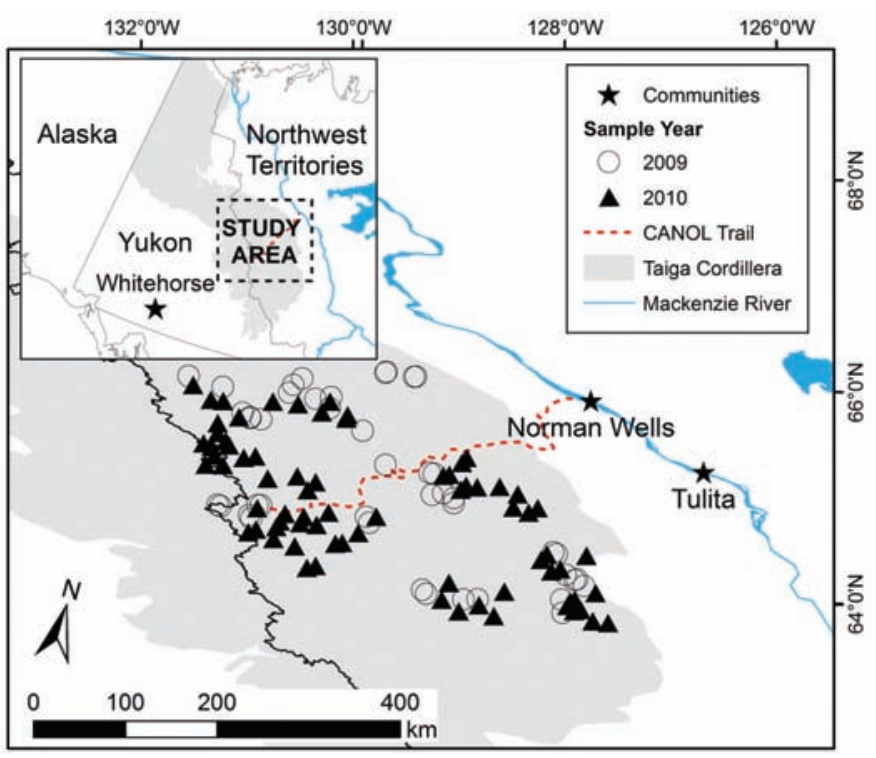

FIG. 1. Locations of point-count grids surveyed in the Taiga Cordillera, Mackenzie Mountains, Northwest Territories, 2009 and 2010.

communities found in the low Arctic tundra. The remoteness of the Mackenzie Mountains has limited human activity to some mineral exploration and development, a few subsistence and sport hunting camps, and remnants of a WW II-era road known as the CANOL (Fig. 1).

\section{Bird Surveys}

Prior to field surveys, we used the Canadian Forest Service's Earth Observation for the Sustainable Development of Forests digital land classification (EOSD; Wood et al., 2002; $25 \mathrm{~m}$ pixel resolution) to identify habitat types in the study area and determine the proportional abundance of each type to allocate sampling effort. Bird surveys were completed as part of an assessment of a proposed protected area, and survey sites were limited to those within the proposed boundary. We used a random generator in ArcGIS 10 (ESRI, 2011) to select sampling sites on the basis of habitat type. Sampled habitats included coniferous forest, deciduous forest, shrub (short and tall), alpine tundra, and openwater wetlands (with adjacent treed uplands).

Breeding bird surveys were conducted from 15 to 26 June 2009 and from 11 to 29 June 2010. Because this remote study area had no roads, we accessed survey locations by helicopter. Sampling locations were at least $150 \mathrm{~m}$ from the helicopter landing site, and observers waited at least $10 \mathrm{~min}$ utes between the drop-off and the start of a point-count to allow birds to resume their normal behaviours (e.g., singing, foraging). Surveys were performed only in favourable weather (e.g., no precipitation, winds $\leq 3$ Beaufort scale) and typically started at local sunrise and stopped five hours later. Birds were surveyed using a point-count technique: all birds within a 10-minute time period were recorded (Ralph et al., 1993) as heard, or seen but not heard. Three point-count stations, representing a survey grid, were situated within a homogenous habitat type and placed at least $300 \mathrm{~m}$ apart to avoid double-sampling of birds (Matsuoka et al., 2012). Locations of point-count stations within a grid were selected to effectively survey the habitat type (e.g., linearly along ridges or open water, or in triangles in larger homogeneous habitats). Point-count stations were located a minimum of $100 \mathrm{~m}$ from the habitat edge, where possible, except in wetlands, where point-count stations were situated within $10 \mathrm{~m}$ of open water.

To increase sample size and because skilled observers were not available during both years of the study, 120 pointcount stations were recorded using omni-directional Earthsong Series E3 Biomonitoring System CZM microphones (Riverforks Research Corp.; Hobson et al., 2002), and the recordings were later transcribed. Comparisons between point-counts conducted in the field and recordings of the same point counts typically result in similar estimates of abundance for birds (Hobson et al., 2002; Campbell and Francis, 2011); therefore, data were pooled for analysis. All birds detected during point-counts were noted regardless of their perceived distance from the observer or microphone because observer estimates of distances to vocalizing birds from recordings and in the field are typically inaccurate (Alldredge et al., 2007). Field observers alternated between habitat types and observation times to reduce confounding of observer, habitat, and temporal effects.

\section{Habitat Classification}

Habitat within a $100 \mathrm{~m}$ radius of each point-count station was classified into one of six habitat types by visually estimating vegetation structure and composition. Percent composition of tree species ( $>3 \mathrm{~m}$ tall), tree cover, average height of shrubs, dominant ground cover (herb, barren, bryoid, ice) and aquatic characteristics (open water, aquatic vegetation) were estimated. Point-count stations containing $70 \%$ or higher coniferous tree species composition (i.e., black spruce) covering $10 \%$ or more of the $100 \mathrm{~m}$ radius were classified as conifer habitats (Table 1). Stations containing 30\% to $100 \%$ deciduous tree species (e.g., trembling aspen, paper birch) composition covering $10 \%$ or more of the $100 \mathrm{~m}$ radius were classified as deciduous habitat. Pointcount stations with shrubs at least $1 \mathrm{~m}$ or higher and covering more than $15 \%$ were classified as tall shrub habitats, and stations with shrubs under $1 \mathrm{~m}$ tall covering more than $15 \%$ were classified as short shrub habitats. Stations with bryophyte or bare ground covering $85 \%$ or more of the $100 \mathrm{~m}$ radius, with less than $15 \%$ shrub cover and less than $10 \%$ tree cover, were classified as alpine tundra habitats. Point-count stations were classified as wetland if they were adjacent to shores of open water wetlands. Wetland classes all had coniferous forest in the upland, and point-counts were completed within $15 \mathrm{~m}$ of the water's edge. All forested habitats were estimated to be more than 50 years old, and early successional habitats (e.g., burned areas) were not sampled during this study. 
$334 \cdot$ K.J. KARDYNAL et al.

TABLE 1. Parameters used to classify point counts into habitat groups in the Mackenzie Mountains, Northwest Territories.

\begin{tabular}{lccclc}
\hline \hline Habitat type & $\begin{array}{c}\text { Tree } \\
\text { height }(\mathrm{m})\end{array}$ & $\begin{array}{c}\text { Tree } \\
\text { cover }\end{array}$ & $\begin{array}{c}\text { Shrub } \\
\text { cover }\end{array}$ & Species composition & $\begin{array}{c}\text { Sample } \\
\text { size (n) }\end{array}$ \\
\hline Alpine tundra & N/A & $<10 \%$ & $\leq 15 \%$ & Dominated by graminoid and bryophyte vegetation & 95 \\
Conifer & $\geq 3 \mathrm{~m}$ & $\geq 10 \%$ & $<90 \%$ & $70 \%$ or more coniferous tree species over 1 m tall & 80 \\
Deciduous & $\geq 3 \mathrm{~m}$ & $\geq 10 \%$ & $<90 \%$ & $30 \%$ to $100 \%$ deciduous tree species & 12 \\
Short shrub & $<3 \mathrm{~m}$ & $<10 \%$ & $>15 \%$ & Dominated by shrub species (e.g., Betula nana) less than 1 m tall & 69 \\
Tall shrub & $<3 \mathrm{~m}$ & $<10 \%$ & $>15 \%$ & Dominated by shrub species (e.g., Salix spp., Betula nana) 1 m or higher & 79 \\
Wetland & $\geq 3 \mathrm{~m}$ & $\geq 10 \%$ & $<90 \%$ & Within $15 \mathrm{~m}$ of an open-water wetland, $70 \%$ or more coniferous tree species over 1 m tall & 27 \\
\hline \hline
\end{tabular}

\section{Data Analysis}

Prior to analysis, bird abundance data at the pointcount level were square-root transformed to control for the influence of abundant species in the analyses (McCune and Grace, 2002). Individuals detected by sight only (i.e., no auditory detection) flying over the point-count station (assumed not breeding within the target habitat), species not surveyed well using point-counts, and species detected fewer than three times or at fewer than three stations were excluded from subsequent analyses. All analyses were conducted using point-count level data to account for heterogeneity in habitats surveyed in a survey grid. To test for potential differences in bird community composition between habitat groups, we used a multiple response permutation procedure (MRPP). Data do not have to meet the assumption of normal distributions making MRPP a robust analytical method for community data. MRPP produces a measure of the degree of separation between groups $(\mathrm{T})$ and a measure of within-group agreement (A) (McCune and Grace, 2002). MRPP was conducted using the Euclidean distance measure with the vegan package (Oksanen et al., 2013) in program R (R Development Core Team, 2013).

We used non-metric multidimensional scaling (NMS) to provide a graphical depiction of the relationship among bird communities in the surveyed habitat types. NMS is a robust ordination technique that performs well with non-normal datasets and uses rank order correlations instead of requiring linear relationships among variables. NMS analysis was conducted using the Euclidean distance measure in PC Ord 5 (McCune and Grace, 2002) with a random starting configuration and 900 runs of the data. Resulting ordination plots assisted with visual interpretation of the MRPP results by displaying the association of species with habitat types and gradients (McCune and Grace, 2002).

Indicator species analysis (ISA) was used to determine the abundance and frequency of occurrence of each bird species in each habitat (Dufrêne and Legendre, 1997), and groups of habitats (De Cáceres and Legendre, 2009). ISA is a non-parametric statistical method that calculates an indicator value by multiplying the abundance of each species in a particular group by the relative frequency of the species occurrence in the sample of each group (Dufrêne and Legendre, 1997; McCune and Grace, 2002). The significance of indicator values is evaluated using a Monte Carlo randomization procedure, in which samples are reassigned and recalculated and used to estimate the probability of the values occurring by chance (McCune and Grace, 2002). Indicator values range from 0 to 100 , and a maximum indicator value (i.e., 100) is obtained when a species is unique to a group (i.e., habitat) and is found in all samples of that group. ISA analysis was performed using indicspecies version 1.7.0 (De Cáceres and Legendre, 2009) in Program R (R Core Development Team, 2013).

We calculated bird community richness from individualbased species rarefaction curves, which use the repeated re-sampling of individuals from the dataset rather than sites (Gotelli and Colwell, 2001). This method provides the expected number of species drawn randomly from the sample, but does not "replace" individuals already sampled. We produced rarefaction estimates using the package vegan (Oksanen et al., 2013) in program R (R Core Development Team, 2013). Sufficient sampling for each group is attained once a curve reaches an asymptote.

\section{RESULTS}

A total of 3291 birds from 85 species were detected over the two years of surveys at 376 point-count stations. After removing species with fewer than three observations, species not reliably censused using point-count methods (e.g., raptors), and those flying over the point-count area, we had 3048 individual birds from 51 species to include in the analyses. The MRPP of all habitats was significant $(p<0.005)$, indicating that our a priori selection of habitat types would be useful for further analyses of species and communities $(\mathrm{T}=-78.90, \mathrm{~A}=0.11)$. Pair-wise comparisons of habitats using MRPP were also statistically significant (all $p$-values at least $<0.01$ ).

The NMS ordination results showed considerable separation in species composition between most habitat types in the two-dimensional solution (Fig. 2). Stress of the final solution was 14.1, which is a satisfactory level for community data (McCune and Grace, 2002). Stability of the final solution was assessed by plotting stress versus iteration (McCune and Grace, 2002). The number of iterations to achieve the final solution was 500, and final instability was 0.0346 . We used a varimax rotation, which optimizes visualization of clusters of species and habitats (Mather, 1976). The first two axes of the NMS accounted for $69 \%$ of the data matrix (Axis $1=15 \%$, Axis $2=54 \%$ ). The ordination indicated that bird communities associated with treed habitats were aligned along Axis 1 generally from conifer (left) 


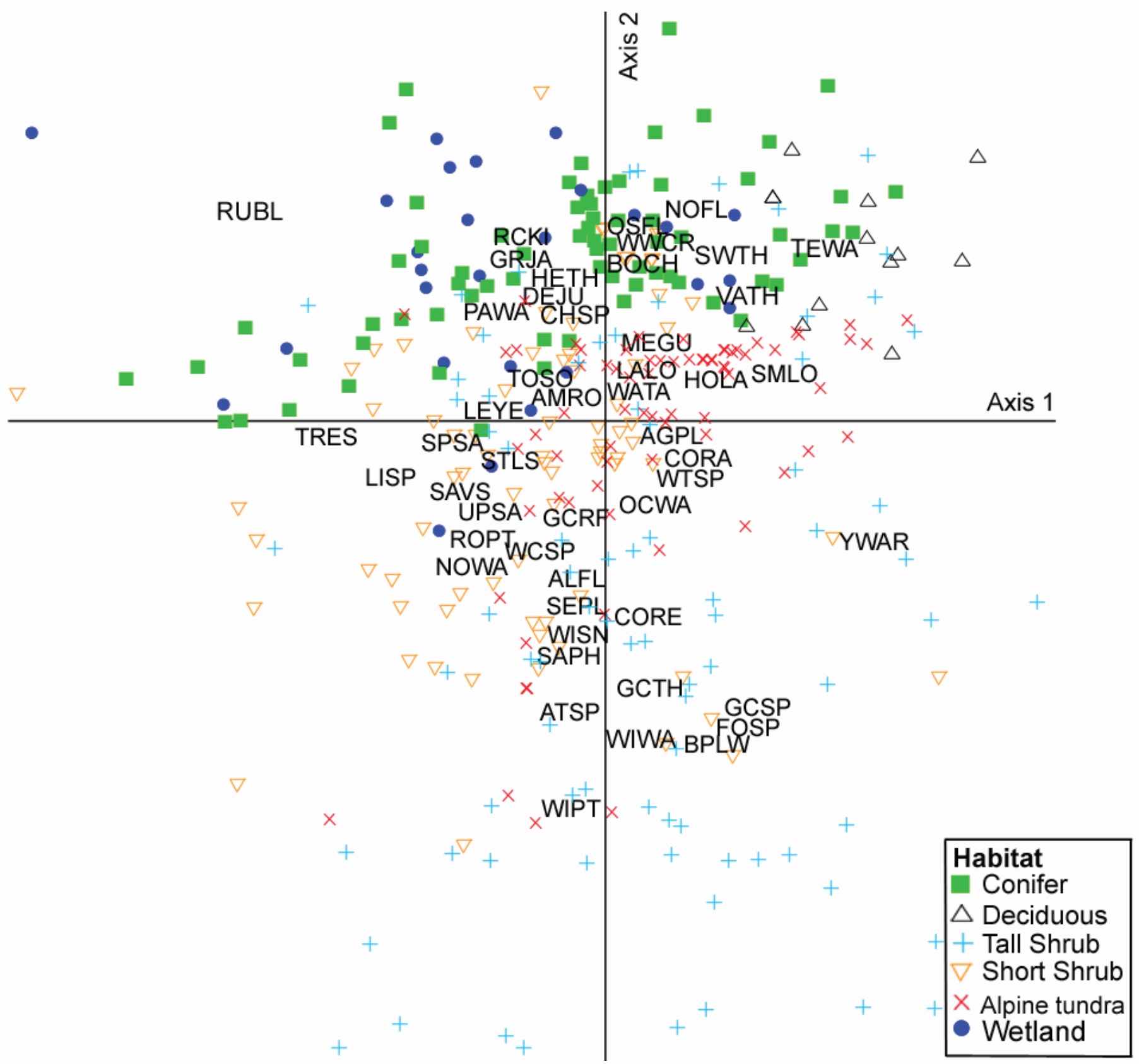

FIG. 2. Non-metric multidimensional scaling (NMS) ordination of bird communities in six habitat types surveyed in the Mackenzie Mountains, Northwest Territories, 2009 and 2010. Common and scientific names for species codes are listed in Table 2.

to wetland (center) to deciduous (right) and Axis 2 represented a gradient from high (bottom) to low (top) shrub density. There is considerable overlap in treed habitats (conifer, deciduous, and wetland) and greater divergence between treed, shrub, and alpine habitats. Alpine habitats contained the most unique bird community, which overlapped the least with other habitat types. Species codes used in the NMS ordination are listed in Table 2.

From the indicator species analysis, a total of 32 species had significant indicator values for one $(\mathrm{n}=15)$ or more $(\mathrm{n}=17)$ habitats (Table 2). Tall shrub habitat had the most indicator species $(\mathrm{n}=6)$ associated with it, including Willow Ptarmigan (Lagopus lagopus), Gray-cheeked Thrush
(Catharus minimus), Alder Flycatcher (Empidonax alnorum), Wilson's Warbler (Cardellina pusilla), Fox Sparrow (Passerella iliaca), and Golden-crowned Sparrow (Zonotrichia atricapilla). Five species were significant indicators of alpine tundra habitat: American Golden-Plover (Pluvialis dominica), American Pipit (Anthus rubescens), Horned Lark (Eremophila alpestris), Smith's Longspur (Calcarius pictus), and Lapland Longspur (Calcarius lapponicus). Deciduous forest habitats had three species with significant indicators only for this habitat type, including Swainson's Thrush (Catharus ustulatus), Tennessee Warbler (Oreothlypis peregrina), and Varied Thrush (Ixoreus naevius). One species, Rusty Blackbird (Euphagus carolinus), was a 
TABLE 2. Indicator values (combining both abundance and frequency of occurrence) derived from indicator species analysis (ISA) for species in habitats or groups of habitats in the Mackenzie Mountains, Northwest Territories, 2009 and $2010 .{ }^{1}$ Values under each habitat represent the mean number of detections $( \pm \mathrm{SE})$ for that habitat.

\begin{tabular}{|c|c|c|c|c|c|c|c|c|c|}
\hline Common and scientific name & Code & Conifer & Deciduous & Tall shrub & Short shrub & Alpine tundra & Wetland & Indicator value & $p$-value \\
\hline $\begin{array}{l}\text { American Golden-Plover } \\
\text { Pluvialis dominica }\end{array}$ & AGPL & - & - & - & - & $0.17 \pm 0.05$ & - & 36.2 & 0.007 \\
\hline $\begin{array}{l}\text { Alder Flycatcher } \\
\text { Empidonax alnorum }\end{array}$ & ALFL & $0.01 \pm 0.01$ & - & $0.06 \pm 0.03$ & - & - & - & 22.7 & 0.025 \\
\hline $\begin{array}{l}\text { American Pipit } \\
\text { Anthus rubescens }\end{array}$ & AMPI & - & - & $0.04 \pm 0.02$ & $0.16 \pm 0.04$ & $0.60 \pm 0.07$ & - & 61.1 & 0.001 \\
\hline $\begin{array}{l}\text { American Robin } \\
\quad \text { Turdus migratorius }\end{array}$ & AMRO & $1.05 \pm 0.10$ & $0.42 \pm 0.15$ & $0.78 \pm 0.10$ & $0.83 \pm 0.09$ & $0.41 \pm 0.06$ & $1.07 \pm 0.16$ & 75.5 & 0.001 \\
\hline $\begin{array}{l}\text { American Tree Sparrow } \\
\text { Spizella arborea }\end{array}$ & ATSP & $0.01 \pm 0.01$ & - & $2.06 \pm 0.21$ & $1.15 \pm 0.21$ & $0.39 \pm 0.10$ & $0.11 \pm 0.06$ & 64.9 & 0.001 \\
\hline $\begin{array}{l}\text { Boreal Chickadee } \\
\quad \text { Poecile hudsonicus }\end{array}$ & $\mathrm{BOCH}$ & - & - & $0.02 \pm 0.02$ & - & - & $0.07 \pm 0.05$ & 23.6 & 0.128 \\
\hline $\begin{array}{l}\text { Blackpoll Warbler } \\
\text { Setophaga striata }\end{array}$ & BPLW & - & - & $0.15 \pm 0.05$ & $0.01 \pm 0.01$ & - & $0.07 \pm 0.05$ & 32.3 & 0.012 \\
\hline $\begin{array}{l}\text { Chipping Sparrow } \\
\text { Spizella passerina }\end{array}$ & CHSP & $0.61 \pm 0.07$ & $0.17 \pm 0.11$ & $0.21 \pm 0.05$ & $0.25 \pm 0.07$ & $0.01 \pm 0.01$ & $0.44 \pm 0.14$ & 55.5 & 0.001 \\
\hline $\begin{array}{l}\text { Common Raven } \\
\text { Corvus corax }\end{array}$ & CORA & $0.01 \pm 0.01$ & - & $0.02 \pm 0.02$ & $0.01 \pm 0.01$ & $0.06 \pm 0.02$ & $0.04 \pm 0.04$ & 19.2 & 0.505 \\
\hline $\begin{array}{l}\text { Common Redpoll } \\
\text { Acanthis flammea }\end{array}$ & CORE & $0.04 \pm 0.02$ & - & $0.27 \pm 0.06$ & $0.11 \pm 0.04$ & $0.07 \pm 0.03$ & $0.07 \pm 0.05$ & 36.0 & 0.041 \\
\hline $\begin{array}{l}\text { Dark-eyed Junco } \\
\text { Junco hyemalis }\end{array}$ & DEJU & $1.40 \pm 0.11$ & $0.25 \pm 0.18$ & $0.53 \pm 0.09$ & $0.29 \pm 0.06$ & $0.01 \pm 0.01$ & $1.30 \pm 0.21$ & 73.3 & 0.001 \\
\hline $\begin{array}{l}\text { Fox Sparrow } \\
\quad \text { Passerella iliaca }\end{array}$ & FOSP & - & - & $0.32 \pm 0.08$ & $0.03 \pm 0.02$ & $0.01 \pm 0.01$ & - & 44.2 & 0.002 \\
\hline $\begin{array}{l}\text { Gray-crowned Rosy-Finch } \\
\text { Leucosticte tephrocotis }\end{array}$ & GCRF & - & - & $0.02 \pm 0.02$ & $0.01 \pm 0.01$ & $0.05 \pm 0.02$ & $0.04 \pm 0.04$ & 18.6 & 0.456 \\
\hline $\begin{array}{r}\text { Golden-crowned Sparrow } \\
\text { Zonotrichia atricapilla }\end{array}$ & GCSP & - & - & $0.26 \pm 0.08$ & $0.06 \pm 0.04$ & $0.06 \pm 0.04$ & - & 31.7 & 0.021 \\
\hline $\begin{array}{l}\text { Gray-cheeked Thrush } \\
\text { Catharus minimus }\end{array}$ & GCTH & $0.15 \pm 0.07$ & - & $0.79 \pm 0.14$ & $0.14 \pm 0.05$ & $0.05 \pm 0.03$ & $0.07 \pm 0.05$ & 51.0 & 0.002 \\
\hline $\begin{array}{l}\text { Gray Jay } \\
\quad \text { Perisoreus canadensis }\end{array}$ & GRJA & $0.41 \pm 0.06$ & $0.17 \pm 0.11$ & $0.09 \pm 0.04$ & $0.13 \pm 0.04$ & $0.01 \pm 0.01$ & $0.37 \pm 0.09$ & 53.4 & 0.001 \\
\hline $\begin{array}{l}\text { Hermit Thrush } \\
\quad \text { Catharus guttatus }\end{array}$ & НЕТН & $0.13 \pm 0.04$ & $0.17 \pm 0.11$ & $0.10 \pm 0.05$ & - & - & $0.07 \pm 0.05$ & 30.3 & 0.016 \\
\hline $\begin{array}{l}\text { Horned Lark } \\
\quad \text { Eremophila alpestris }\end{array}$ & HOLA & $0.01 \pm 0.01$ & - & - & - & $0.68 \pm 0.09$ & - & 65.9 & 0.001 \\
\hline $\begin{array}{l}\text { Lapland Longspur } \\
\quad \text { Calcarius lapponicus }\end{array}$ & LALO & - & - & - & - & $0.20 \pm 0.06$ & - & 31.8 & 0.022 \\
\hline $\begin{array}{l}\text { Lesser Yellowlegs } \\
\text { Tringa flavipes }\end{array}$ & LEYE & $0.01 \pm 0.01$ & $0.08 \pm 0.08$ & $0.06 \pm 0.03$ & - & $0.01 \pm 0.01$ & $0.19 \pm 0.08$ & 30.9 & 0.025 \\
\hline $\begin{array}{l}\text { Lincoln's Sparrow } \\
\text { Melospiza lincolnii }\end{array}$ & LISP & $0.10 \pm 0.03$ & - & $0.16 \pm 0.06$ & $0.30 \pm 0.07$ & $0.02 \pm 0.01$ & $0.26 \pm 0.09$ & 41.3 & 0.01 \\
\hline $\begin{array}{l}\text { Mew Gull } \\
\quad \text { Larus canus }\end{array}$ & MEGU & - & - & - & $0.01 \pm 0.01$ & $0.01 \pm 0.01$ & $0.07 \pm 0.05$ & 23.8 & 0.101 \\
\hline $\begin{array}{l}\text { Northern Flicker } \\
\text { Colaptes auratus }\end{array}$ & NOFL & $0.06 \pm 0.03$ & $0.08 \pm 0.08$ & - & - & - & $0.07 \pm 0.05$ & 25.9 & 0.033 \\
\hline $\begin{array}{l}\text { Northern Waterthrush } \\
\quad \text { Seiurus noveboracensis }\end{array}$ & NOWA & - & - & $0.02 \pm 0.02$ & $0.01 \pm 0.01$ & $0.01 \pm 0.01$ & - & 12.5 & 0.832 \\
\hline $\begin{array}{l}\text { Orange-crowned Warbler } \\
\text { Oreothlypis celata }\end{array}$ & OCWA & $0.03 \pm 0.02$ & $0.17 \pm 0.11$ & $0.33 \pm 0.08$ & $0.09 \pm 0.04$ & - & $0.11 \pm 0.06$ & 40.0 & 0.005 \\
\hline $\begin{array}{l}\text { Olive-sided Flycatcher } \\
\text { Contopus cooperi }\end{array}$ & OSFL & $0.05 \pm 0.03$ & - & $0.02 \pm 0.02$ & $0.01 \pm 0.01$ & - & - & 16.2 & 0.448 \\
\hline $\begin{array}{l}\text { Palm Warbler } \\
\quad \text { Setophaga palmarum }\end{array}$ & PAWA & $0.09 \pm 0.04$ & - & $0.01 \pm 0.01$ & - & - & $0.07 \pm 0.05$ & 26.3 & 0.035 \\
\hline $\begin{array}{l}\text { Ruby-crowned Kinglet } \\
\text { Regulus calendula }\end{array}$ & RCKI & $0.06 \pm 0.03$ & - & $0.02 \pm 0.02$ & $0.05 \pm 0.03$ & - & - & 22.2 & 0.132 \\
\hline $\begin{array}{l}\text { Rock Ptargmigan } \\
\text { Lagopus muta }\end{array}$ & ROPT & - & - & $0.04 \pm 0.03$ & $0.04 \pm 0.02$ & - & $0.04 \pm 0.04$ & 18.0 & 0.328 \\
\hline $\begin{array}{l}\text { Rusty Blackbird } \\
\text { Euphagus carolinus }\end{array}$ & RUBL & $0.03 \pm 0.03$ & - & - & - & - & $0.30 \pm 0.17$ & 36.9 & 0.004 \\
\hline $\begin{array}{l}\text { Say's Phoebe } \\
\text { Sayornis saya }\end{array}$ & SAPH & - & - & $0.05 \pm 0.02$ & $0.01 \pm 0.01$ & $0.02 \pm 0.01$ & - & 17.2 & 0.409 \\
\hline $\begin{array}{l}\text { Savannah Sparrow } \\
\quad \text { Passerculus sandwichensi }\end{array}$ & $\underset{\text { is }}{\text { SAVS }}$ & $0.40 \pm 0.10$ & - & $0.43 \pm 0.09$ & $0.74 \pm 0.14$ & $0.69 \pm 0.09$ & $0.85 \pm 0.17$ & 59.0 & 0.011 \\
\hline $\begin{array}{l}\text { Semipalmated Plover } \\
\quad \text { Charadrius semipalmatus }\end{array}$ & SEPL & - & - & $0.01 \pm 0.01$ & - & $0.05 \pm 0.02$ & - & 20.1 & 0.24 \\
\hline $\begin{array}{l}\text { Smith's Longspur } \\
\text { Calcarius pictus }\end{array}$ & SMLO & - & - & - & - & $0.15 \pm 0.05$ & - & 31.8 & 0.017 \\
\hline
\end{tabular}


TABLE 2. Indicator values (combining both abundance and frequency of occurrence) derived from indicator species analysis (ISA) for species in habitats or groups of habitats in the Mackenzie Mountains, Northwest Territories, 2009 and $2010 .{ }^{1}$ Values under each habitat represent the mean number of detections $( \pm \mathrm{SE})$ for that habitat - continued:

\begin{tabular}{|c|c|c|c|c|c|c|c|c|c|}
\hline Common and scientific name & Code & Conifer & Deciduous & Tall shrub & Short shrub & Alpine tundra & Wetland & Indicator value & $p$-value \\
\hline $\begin{array}{l}\text { Spotted Sandpiper } \\
\text { Actitis macularia }\end{array}$ & SPSA & - & - & - & - & $0.02 \pm 0.02$ & $0.04 \pm 0.04$ & 16.4 & 0.163 \\
\hline $\begin{array}{l}\text { Stilt Sandpiper } \\
\quad \text { Calidris himantopus }\end{array}$ & STLS & - & - & - & - & $0.04 \pm 0.02$ & - & 20.1 & 0.162 \\
\hline $\begin{array}{l}\text { Swainson's Thrush } \\
\quad \text { Catharus ustulatus }\end{array}$ & SWTH & $0.40 \pm 0.09$ & $1.70 \pm 0.09$ & $0.12 \pm 0.04$ & $0.06 \pm 0.03$ & $0.01 \pm 0.01$ & $0.11 \pm 0.06$ & 81.9 & 0.001 \\
\hline $\begin{array}{l}\text { Tennessee Warbler } \\
\text { Oreothlypis peregrina }\end{array}$ & TEWA & $0.01 \pm 0.01$ & $0.42 \pm 0.19$ & - & - & - & $0.04 \pm 0.04$ & 54.2 & 0.001 \\
\hline $\begin{array}{l}\text { Townsend's Solitaire } \\
\quad \text { Myadestes townsendi }\end{array}$ & TOSO & $0.06 \pm 0.03$ & - & - & $0.08 \pm 0.04$ & - & - & 25.2 & 0.06 \\
\hline $\begin{array}{l}\text { Tree Swallow } \\
\quad \text { Tachycineta bicolor }\end{array}$ & TRES & - & - & $0.01 \pm 0.01$ & $0.01 \pm 0.01$ & - & $0.04 \pm 0.04$ & 14.9 & 0.293 \\
\hline $\begin{array}{l}\text { Upland Sandpiper } \\
\text { Bartramia longicauda }\end{array}$ & UPSA & $0.03 \pm 0.02$ & - & $0.04 \pm 0.02$ & - & $0.04 \pm 0.02$ & - & 18.6 & 0.499 \\
\hline $\begin{array}{l}\text { Varied Thrush } \\
\text { Ixoreus naevius }\end{array}$ & VATH & $0.28 \pm 0.06$ & $1.42 \pm 0.23$ & $0.25 \pm 0.06$ & $0.05 \pm 0.03$ & - & $0.11 \pm 0.06$ & 72.9 & 0.001 \\
\hline $\begin{array}{l}\text { Wandering Tattler } \\
\quad \text { Heteroscelus incanus }\end{array}$ & WATA & $0.01 \pm 0.01$ & - & $0.01 \pm 0.01$ & - & $0.01 \pm 0.01$ & - & 10.7 & 1 \\
\hline $\begin{array}{l}\text { White-crowned Sparrow } \\
\text { Zonotrichia leucophrys }\end{array}$ & WCSP & $0.81 \pm 0.13$ & $0.08 \pm 0.08$ & $2.20 \pm 0.19$ & $2.44 \pm 0.20$ & $0.58 \pm 0.10$ & $0.70 \pm 0.18$ & 77.2 & 0.001 \\
\hline $\begin{array}{l}\text { Willow Ptarmigan } \\
\text { Lagopus lagopus }\end{array}$ & WIPT & $0.01 \pm 0.01$ & - & $0.43 \pm 0.09$ & $0.04 \pm 0.03$ & $0.04 \pm 0.02$ & $0.07 \pm 0.05$ & 43.2 & 0.001 \\
\hline $\begin{array}{l}\text { Wilson's Snipe } \\
\quad \text { Gallinago delicata }\end{array}$ & WISN & - & - & $0.12 \pm 0.04$ & $0.04 \pm 0.02$ & $0.10 \pm 0.04$ & - & 29.1 & 0.043 \\
\hline $\begin{array}{l}\text { Wilson's Warbler } \\
\text { Cardellina pusilla }\end{array}$ & WIWA & $0.01 \pm 0.01$ & $0.08 \pm 0.08$ & $1.75 \pm 0.20$ & $0.25 \pm 0.07$ & $0.17 \pm 0.06$ & $0.07 \pm 0.05$ & 64.3 & 0.001 \\
\hline $\begin{array}{l}\text { White-throated Sparrow } \\
\text { Zonotrichia albicollis }\end{array}$ & WTSP & $0.01 \pm 0.01$ & - & $0.02 \pm 0.02$ & - & $0.01 \pm 0.01$ & - & 12.4 & 0.952 \\
\hline $\begin{array}{l}\text { White-winged Crossbill } \\
\text { Loxia leucoptera }\end{array}$ & WWCR & $0.09 \pm 0.03$ & $0.08 \pm 0.08$ & $0.01 \pm 0.01$ & $0.03 \pm 0.03$ & - & $0.04 \pm 0.04$ & 25.7 & 0.058 \\
\hline $\begin{array}{l}\text { Yellow-rumped Warbler } \\
\text { Setophaga coronata }\end{array}$ & YRWA & $0.90 \pm 0.09$ & $0.58 \pm 0.15$ & $0.19 \pm 0.06$ & $0.23 \pm 0.06$ & - & $0.85 \pm 0.16$ & 73.0 & 0.001 \\
\hline $\begin{array}{l}\text { Yellow Warbler } \\
\text { Setophaga petechia }\end{array}$ & YWAR & - & $0.08 \pm 0.08$ & $0.10 \pm 0.04$ & - & $0.02 \pm 0.01$ & - & 25.9 & 0.057 \\
\hline
\end{tabular}

${ }^{1}$ Species with significant indicator values $(p<0.05)$ and habitats for which the highest indicator values occur are in bold. See text for a description of indicator species analysis.

significant indicator species of wetland habitat, and no species were significant indicators of conifer habitats only. For species with significant indicator values for groups of habitats, six were indicators of two habitats, eight were indicators of three habitats, and three species were indicators of four or more habitats (Table 2).

Results from the individual-based rarefaction analysis showed that tall shrub habitat had the highest estimated species richness ( 37 species). This was followed by alpine, conifer, short shrub, and wetland sites having similar richness estimates ( $28-30$ species). Deciduous habitat had the lowest estimated species richness (14 species). However, rarefaction curves in deciduous and wetland habitats did not reach an asymptote, suggesting that sample sizes for these habitats were insufficient to detect maximum species richness (Gotelli and Colwell, 2001).

\section{DISCUSSION}

Our study is the first systematic investigation of bird communities in the northern Mackenzie Mountains and provides vital baseline information on abundance, richness, distribution, and bird-habitat relationships that can be used for monitoring and conservation purposes. Habitats of the Mackenzie Mountains include forested slopes and valleys, dense shrubs, wetlands, bare talus slopes, and alpine areas resembling Arctic tundra. This structural diversity contributes to the unique and diverse bird communities, with significant differences in community composition between major habitat types. We are unable to compare our results with other studies in similar northern mountainous habitats because of the paucity of bird research in those areas. When compared to southern non-montane boreal forest, bird species in forested habitats in our study are less abundant and bird communities are not as rich in similar habitats at the point-count scale (Machtans and Latour, 2003). This could be a result of climatic limitations on breeding phenology, lower structural heterogeneity of vegetation, and potentially lower prey abundance (Zhang et al., 2012; Cumming et al., 2014). In addition, Machtans and Latour (2003) used a point-count radius of only $50 \mathrm{~m}$, in contrast to the unlimited distance point-count radius used in our study, which makes 
the reduced abundance and richness of birds found in our northern study area even more striking.

Bird communities in treed habitats, including conifer and deciduous forests, and those associated with open-water wetlands showed high overlap in the NMS ordination, presumably as a result of their similar vertical vegetation structure (e.g., trees). Conifer habitats had no significant indicator species associated only with this habitat, but they shared four significant indicator species typical of coniferous forest (Dark-eyed Junco Junco hyemalis, Chipping Sparrow Spizella passerina, Gray Jay Perisoreous canadensis, and Hermit Thrush Catharus guttatus) with wetland sites. This result was expected because upland habitat adjacent to wetlands was dominated by coniferous forests similar to those in the conifer habitat category. Deciduous habitats are scarce in our study area, occurring mostly in small patches in low-elevation river valleys, and they do not exhibit the higher structural heterogeneity of this forest type farther south, which likely results in fewer deciduous-associated bird species on the landscape. Openwater wetlands are not common elements of the study area landscape, but they provide unique and important habitat for some species in this region. Rusty Blackbird, a species listed as of special concern in the Canadian Species at Risk Act, was the only significant indicator species for wetlands. Some species considered riparian/wetland specialists (e.g., Lesser Yellowlegs Tringa flavipes, Blackpoll Warbler Setophaga striata) were also associated with this habitat type in combination with other habitats. The low number of indicator species for wetland habitats is likely due to the lack of a riparian zone that would attract riparian birds (Morissette et al., 2013) and make wetland habitat different from the conifer category.

Dense, tall shrubs provide important habitats in the Mackenzie Mountains for a rich and unique assemblage of bird species. Sites in the tall shrub category typically consisted of very dense shrub cover with ample vertical structure, which provides habitat for a greater number of species than other habitat types in the study area. Short shrub habitats did not contain a unique bird community with respect to other habitats. Although species richness was similar to that of most other habitat types, it did not contain any species that were significant indicators of this habitat type. The relative ubiquity of bird species in this habitat may occur because it is transitional from alpine tundra to tall shrub habitats; it does not provide either sufficient open graminoid-dominated structure of the former habitat or the dense, vertical structure of the latter. Alpine tundra represents a unique habitat type in our study area that contains elements most similar to Arctic tundra (e.g., grass/sedge dominated) and is typically devoid of woody vertical structure (shrubs and trees). Bird species associated with alpine tundra habitats in our study include species typically found in Arctic tundra habitats (e.g., American Golden-Plover, Lapland Longspur; Poole, 2005). Alpine habitats may be most at risk from climate change: it is predicted that shrubs and trees will encroach on these graminoid-dominated regions with a warming climate (Myers-Smith et al., 2011; Lantz et al., 2013) potentially influencing bird abundance, phenology, and community structure (McKinnon et al., 2012; Chamberlain et al., 2013). Several alpine species in our study are declining as a result of climate change or are moderately to highly vulnerable to climate change and its associated effects (NABCI Canada, 2012; Lehikoinen et al., 2014).

Several bird species observed during our study were not previously known to inhabit this region of the Mackenzie Mountains or are outside published ranges (e.g., Poole, 2005). These species were typically found in alpine tundra, shrub, and wetland/riverine habitats and included the Redthroated Loon (Gavia stellata), Wandering Tattler (Heteroscelus incanus), Long-tailed Duck (Clangula hyemalis), Rough-legged Hawk (Buteo lagopus), American Dipper (Cinclus mexicanus), Harris's Sparrow (Zonotrichia querula), Smith's Longspur, and Lapland Longspur. Some species previously thought to occur only in Canadian Arctic areas, including both longspur species, also inhabit alpine habitats in Europe (Lehikoinen et al., 2014), and their range within the Mackenzie Mountains may be widespread wherever appropriate habitat exists. Evidence of breeding (e.g., nests, territorial defence) was found for most of these species, and observations of these species in the study area are likely to represent extensions of previously published breeding ranges. However, one species (Harris's Sparrow) may have been a vagrant, and others (e.g., Rough-legged Hawk) may only occur in low abundance where appropriate habitat exists.

We were unable to account for detection probabilities of birds in our study because we lacked the high number of detections required for removal modeling (Farnsworth et al., 2002). To reduce the effects of weather, observers, time, and habitat on bird detectability, we surveyed in good weather, had only three skilled observers perform surveys, limited survey times to early mornings, and rotated observers between habitats. Not accounting for detection probabilities can potentially lead to biased results, but adjusting counts to account for detectability may not be particularly effective for small sample sizes (Welsh et al., 2013).

Knowledge of the basic ecology and habitat relationships of many wildlife species in northern Canada, including the Mackenzie Mountains, is extremely limited. Such information is important in providing an understanding of how wildlife species and communities inhabiting these areas will respond to climate change and to increased anthropogenic pressures such as mineral development, and it provides a potential opportunity to plan conservation of biologically important habitats. Although this region is generally considered to have low species richness, we found that the bird diversity of the study area was comparatively high because of its diversity of habitats. Further studies with greater spatial coverage and longer-term datasets are required to determine range extents and trends of montane birds and the abiotic, biotic (e.g., micro-habitat), and anthropogenic factors that influence bird abundance and community structure in the Mackenzie Mountains. 


\section{ACKNOWLEDGEMENTS}

We are grateful to W. Horassi, S. Elke, M. Klaczek, S. Moore (EBA Engineering Consultants) and D. Wilderspin for assisting with data collection. The community of Tulita, Northwest Territories, provided initial support for the ecological assessment of the candidate protected area through the Northwest Territories Protected Areas Strategy. G. Thibault and C. Arsenault were our pilots who navigated the Mackenzie Mountains. Financial Support was provided by Environment Canada (Canadian Wildlife Service).

\section{REFERENCES}

Alldredge, M.W., Simons, T.R., and Pollock, K.H. 2007. A field evaluation of distance measurement error in auditory avian point count surveys. Journal of Wildlife Management 71(8):2759-2766.

http://dx.doi.org/10.2193/2006-161

AMAX Inc. 1983. 1981-1983 MacTung wildlife studies, Yukon/ NWT. 134 p.

Barichello, N. 1983. Selection of nest sites by Gyrfalcons (Falco rusticolus). MS thesis, University of British Columbia, Vancouver, Canada.

Brandt, J.P. 2009. The extent of the North American boreal zone. Environmental Reviews 17:101-161. http://dx.doi.org/10.1139/a09-004

Campbell, M., and Francis, C.M. 2011. Using stereo-microphones to evaluate observer variation in North American breeding bird survey point counts. The Auk 128(2):303-312. http://dx.doi.org/10.1525/auk.2011.10005

Canadian Wildlife Service. 2009. Phase II ecological assessment of the Shúhtagot'iné Néné candidate protected area, Northwest Territories. 55 p. + appendices.

http://www.nwtpas.ca/areas/document-2009-shuhtagotineeaphase2.pdf

Canterbury, G.E., Martin, T.E., Petit, D.R., Petit, L.J., and Bradford, D.F. 2000. Bird communities and habitat as ecological indicators of forest condition in regional monitoring. Conservation Biology 14(2):544-558.

http://dx.doi.org/10.1046/j.1523-1739.2000.98235.x

Chamberlain, D.E., Negro, M., Caprio, E., and Rolando, A. 2013. Assessing the sensitivity of alpine birds to potential future changes in habitat and climate to inform management strategies. Biological Conservation 167:127-135. http://dx.doi.org/10.1016/j.biocon.2013.07.036

Cumming, S.G., Stralberg, D., Lefevre, K.L., Sólymos, P., Bayne, E.M., Fang, S., Fontaine, T., Mazerolle, D., Schmiegelow, F.K.A., and Song, S.J. 2014. Climate and vegetation hierarchically structure patterns of songbird distribution in the Canadian boreal region. Ecography 37(2):137-151. http://dx.doi.org/10.1111/j.1600-0587.2013.00299.x

De Cáceres, M., and Legendre, P. 2009. Associations between species and groups of sites: Indices and statistical inference. Ecology 90(12):3566-3574.

http://dx.doi.org/10.1890/08-1823.1
Dufrêne, M., and Legendre, P. 1997. Species assemblages and indicator species: The need for a flexible asymmetrical approach. Ecological Monographs 67(3):345-366. http://dx.doi.org/10.2307/2963459

Dunn, E.H., Altman, B.L., Bart, J., Beardmore, C.J., Berlanga, H., Blancher, P.J., Butcher, G.S., et al. 2005. High priority needs for range-wide monitoring of North American landbirds. Partners in Flight Technical Series No. 2. Laurel, Maryland: Partners in Flight Science Committee.

http://www.partnersinflight.org/pubs/ts/02-monitoringneeds. pdf

Ecosystem Classification Group. 2010. Ecological regions of the Northwest Territories-Cordillera. Yellowknife: Department of Environment and Natural Resources, Government of the Northwest Territories. $245 \mathrm{p}$.

http://www.enr.gov.nt.ca/sites/default/files/reports/2010 cordillera_report_web2.pdf

Ernakovich, J.G., Hopping, K.A., Berdanier, A.B., Simpson, R.T., Kachergis, E.J., Steltzer, H., and Wallenstein, M.D. 2014. Predicted responses of Arctic and alpine ecosystems to altered seasonality under climate change. Global Change Biology 20(10):3256-3269.

http://dx.doi.org/10.1111/gcb.12568

ESRI (Environmental Systems Research Institute). 2011. ArcGIS desktop 10. Redlands, California: ESRI.

ESTR Secretariat. 2011. Taiga Cordillera Ecozone ${ }^{+}$evidence for key findings summary. Canadian biodiversity: Ecosystem status and trends 2010, Evidence for Key Findings Summary Report No. 1. Ottawa: Canadian Councils of Resource Ministers. vi $+55 \mathrm{p}$.

http://www.speciesatrisk.ca/resource/DOCUMENT/ 4027No.1_Taiga_Cordillera_EKFS_Feb2013_E.pdf

Farnsworth, G.L., Pollock, K.H., Nichols, J.D., Simons, T.R., Hines, J.E., and Sauer, J.R. 2002. A removal model for estimating detection probabilities from point-count surveys. The Auk 119(2):414-425. http://dx.doi.org/10.2307/4089888

Gal, L.P., and Pyle, L.J. 2012. Petroleum potential data (conventional and unconventional) for Horn River Group from 26 exploration wells- NTS 95N, 96C, 96D, 96E, 96F and 106H, Northwest Territories. Geoscience Office, NWT Open Report 2012-009. 41 p. and Microsoft Excel (.xlsx) files.

Gotelli, N.J., and Colwell, R.K. 2001. Quantifying biodiversity: Procedures and pitfalls in the measurement and comparison of species richness. Ecology Letters 4(4):379-391. http://dx.doi.org/10.1046/j.1461-0248.2001.00230.x

Grabowski, M.M., Doyle, F.I., Reid, D.G., Mossop, D., and Talarico, D. 2013. Do Arctic-nesting birds respond to earlier snowmelt? A multi-species study in north Yukon, Canada. Polar Biology 36(8):1097-1105.

http://dx.doi.org/10.1007/s00300-013-1332-6

Hinzman, L.D., Bettez, N.D., Bolton, W.R., Chapin, F.S., Dyurgerov, M.B., Fastie, C.L., Griffith, B., et al. 2005. Evidence and implications of recent climate change in northern Alaska and other Arctic regions. Climatic Change 72(3):251-298. http://dx.doi.org/10.1007/s10584-005-5352-2 
Hobson, K.A., Rempel, R.S., Greenwood, H., Turnbull, B., and Van Wilgenburg, S.L. 2002. Acoustic surveys of birds using electronic recordings: New potential from an omnidirectional microphone system. Wilson Society Bulletin 30(3):709-720.

Lantz, T.C., Marsh, P., and Kokelj, S.V. 2013. Recent shrub proliferation in the Mackenzie Delta uplands and microclimatic implications. Ecosystems 16(1):47-59.

http://dx.doi.org/10.1007/s10021-012-9595-2

Lehikoinen, A., Green, M., Husby, M., Atle Kålås, J., and Lindström, Å. 2014. Common montane birds are declining in northern Europe. Journal of Avian Biology 45(1):3 - 14. http://dx.doi.org/10.1111/j.1600-048X.2013.00177.x

Liang, L., and Kershaw, G.P. 1995. Climate change in the Mackenzie Mountains, N.W.T., Canada. Climate Research $5(1): 1-13$.

http://dx.doi.org/10.3354/cr005001

Machtans, C.S., and Latour, P.B. 2003. Boreal forest songbird communities of the Liard Valley, Northwest Territories, Canada. The Condor 105(1):27-44.

http://dx.doi.org/10.1650/0010-5422(2003)105[27:BFSCOT] 2.0.CO;2

Mather, P.M. 1976. Computational methods of multivariate analysis in physical geography. London: John Wiley and Sons. $532 \mathrm{p}$

Matsuoka, S.M., Bayne, E.M., Sólymos, P., Fontaine, P.C., Cumming, S.G., Schmiegelow, F.K.A., and Song, S.J. 2012. Using binomial distance-sampling models to estimate the effective detection radius of point-count surveys across boreal Canada. The Auk 129(2):268-282.

http://dx.doi.org/10.1525/auk.2012.11190

McCune, B., and Grace, J.B. 2002. Analysis of ecological communities. Gleneden Beach, Oregon: MjM Software. 304 p.

McKinnon, L., Picotin, M., Bolduc, E., Juillet, C., and Bêty, J. 2012. Timing of breeding, peak food availability, and effects of mismatch on chick growth in birds nesting in the High Arctic. Canadian Journal of Zoology 90(8):961 -971. http://dx.doi.org/10.1139/z2012-064

Morissette, J.L., Kardynal, K.J., Bayne, E.M., and Hobson, K.A. 2013. Comparing bird community composition among boreal wetlands: Is wetland classification a missing piece of the habitat puzzle? Wetlands 33(4):653-665.

http://dx.doi.org/10.1007/s13157-013-0421-1

Myers-Smith, I.H., Forbes, B.C., Wilmking, M., Hallinger, M., Lantz, T., Blok, D., Tape, K.D., et al. 2011. Shrub expansion in tundra ecosystems: Dynamics, impacts and research priorities. Environmental Research Letters 6(4): 045509.

http://dx.doi.org/10.1088/1748-9326/6/4/045509

Niemi, G., Hanowski, J., Helle, P., Howe, R., Mönkkönen, M., Venier, L., and Welsh, D. 1998. Ecological sustainability of birds in boreal forests. Conservation Ecology [online] 2(2): 17. http://www.consecol.org/vol2/iss2/art17/
NABCI Canada (North American Bird Conservation Initiative Canada). 2012. The state of Canada's birds, 2012. Ottawa: Environment Canada. 36 p.

Oksanen, J., Blanchet, F.G., Kindt, R., Legendre, P., Minchin, P.R., O’Hara, R.B., Simpson, G.L., Solymos, P., Stevens, M.H.H., and Wagner, H. 2013. vegan: Community Ecology Package. R package version 2.0-10. http://CRAN.R-project.org/package=vegan

Ozyer, C.A. 2012. Shúhtagot'ine Néné Candidate Protected Area Phase II non-renewable resource assessment - minerals. NWT Open File 2012-01. Yellowknife: Northwest Territories Geoscience Office. $51 \mathrm{p}$.

Poole, A., ed. 2005. The birds of North America Online. Ithaca, New York: Cornell Laboratory of Ornithology. http://bna.birds.cornell.edu/BNA/

R Development Core Team. 2013. The R Project for Statistical Computing. Vienna, Austria: The R Foundation. http://www.R-project.org/

Ralph, C.J., Geupel, G.R., Pyle, P., Martin, T.E., and DeSante, D.F. 1993. Handbook of field methods for monitoring landbirds. General Techical Report PSW-GTR-144. Albany, California: Pacific Southwest Research Station, Forest Service, U.S. Department of Agriculture. 41 p.

Rand, A.L. 1946. List of Yukon birds and those of the Canol Road. National Museum of Canada. Bulletin 105, Biological Series No. 33. Ottawa: Mines and Geology Branch, National Museum of Canada. 76 p.

Scotter, G.W., Carbyn, L.N., Neily, W.P., and Henry, J.D. 1985. Birds of Nahanni National Park, Northwest Territories. Special Publication No. 15. Regina: Saskatchewan Natural History Society. 74 p.

Virkkala, R., and Lehikoinen, A. 2014. Patterns of climateinduced density shifts of species: Poleward shifts faster in northern boreal birds than in southern birds. Global Change Biology 20(10):2995-3003.

http://dx.doi.org/10.1111/gcb.12573

Welsh, A.H., Lindenmayer, D.B., and Donnelly, C.F. 2013. Fitting and interpreting occupancy models. PLoS ONE 8(1): e52015. http://dx.doi.org/10.1371/journal.pone.0052015

Wood, J.E., Gillis, M.D., Goodenough, D.G., Hall, R.J., Leckie, D.G., Luther, J.E., and Wulder, M.A. 2002. Earth Observation for Sustainable Development of Forests (EOSD): Project overview. 2002 IEEE International Geoscience and Remote Sensing Symposium, 24-28 June 2002, Toronto, Ontario. Piscataway, New Jersey: IEEE. 1299-1302. http://dx.doi.org/10.1109/igarss.2002.1026097

Zhang, J., Kissling, W.D., and He, F. 2013. Local forest structure, climate and human disturbance determine regional distribution of boreal bird species richness in Alberta, Canada. Journal of Biogeography 40(6):1131 - 1142 . http://dx.doi.org/10.1111/jbi.12063 